$\int \mid$\begin{tabular}{l} 
JURNAL MEGA AKTIVA \\
Email : megaaktiva@ febi.umkendari.ac.id \\
Website : https://megaaktiva.umkendari.ac.id/index.php/Jurnal \\
\hline
\end{tabular}

\title{
PENGARUH INTERNAL CAPITAL ADEQUENCY RATIO (CAR), FINANCING TO DEPOSIT RATIO (FDR), DAN BIAYA OPERASIONAL PER PENDAPATAN OPERASIONAL (BOPO) DALAM PENINGKATAN PROFITABILITAS INDUSTRI BANK SYARIAH DI INDONESIA
}

\author{
${ }^{1}$ Ningsukma Hakiim \\ ${ }^{1}$ Magister Sains Ekonomi Islam, Universitas Airlangga, Surabaya, Indonesia
}

\begin{abstract}
ABSTRAK
Tujuan penelitian ini adalah untuk mengetahui dan menganalisis pengaruh tingkat rasio kesehatan bank yang diukur dengan CAR, FDR, dan BOPO terhadap peningkatan profitabilitas industri Bank Umum Syariah di Indonesia. Data yang dipakai dalam penelitian ini adalah data sekunder antara lain capital adequacy ratio (CAR), likuiditas (FDR), efisiensi operasional (BOPO) dan profitabilitas (ROA) pada industri perbankan umum syariah yang terdaftar di Bank Indonesia. Data tersebut merupakan data time series cross section dari tahun 2010-2012 dan 2013 (hanya pada bulan Januari hingga Maret 2013) yang diperoleh melalui situs resmi statistik perbankan, Bank Indonesia (www.bi.go.id). Untuk menganalisisnya, peneliti menggunakan model regresi linear berganda dengan SPSS 16. Dari hasil pengamatan dan analisis data yang telah dilakukan, kesimpulan pada penelitian ini adalah CAR, FDR, dan BOPO terhadap ROA yang merupakan indikator kesehatan Bank untuk mengukur profitabilitasnya memiliki hubungan yang tinggi. CAR secara parsial tidak berpengaruh signifikan terhadap profitabilitas. Variabel FDR secara parsial berpengaruh negatif dan tidak signifikan terhadap profitabilitas. Berbeda lagi dengan BOPO yang secara parsial berpengaruh negatif dan signifikan terhadap ROA.
\end{abstract}

Kata kunci : CAR, FDR, BOPO, ROA, Bank Umum Syariah

\section{PENDAHULUAN}

Bank sebagai badan usaha yang menghimpun dana dari masyarakat dalam bentuk simpanan dan menyalurkannya kepada masyarakat, dalam bentuk kredit dan atau bentuk-bentuk lainnya dalam rangka meningkatkan taraf hidup rakyat banyak, berikut definisi bank menurut Undang-undang Nomor 10 tahun 1998. Ada tiga macam Bank menurut fungsinya yang beroperasi di Indonesia, yakni Bank Sentral, Bank Umum dan Bank Pengkreditan Rakyat. Dalam menjalankan usaha, dibagi lagi menjadi Bank konvensional dan Bank yang menggunakan prinsip syariah.

Saat ini, pertumbuhan dan perkembangan sistem ekonomi keuangan berlandaskan Syariah Islam di Indonesia, maju sangat pesat. Oleh karena salah satunya Indonesia berpenduduk mayoritas muslim. Kita dapat melihat langsung maupun mendengar di berbagai media sosial yang ada mengenai menjamurnya kegiatan usaha syariah. Indonesia telah diprediksi pula oleh para ekonom syariah bahwa kondisi usaha syariah akan lebih unggul daripada Malaysia di masa yang akan datang.

Mengulas sedikit tentang perkembangan Bank Konvensional di Indonesia. Dalam artikel di Jawa Pos tanggal 7 Februari 2013, menyatakan Indonesia kembali digadang- 
gadang menjadi negara yang paling stabil di tengah kondisi perekonomian global yang tak menentu. Salah satu faktor pendukung fondasi stabilitas ekonomi di Indonesia adalah sektor perbankan. Fitch Ratings, lembaga pemeringkat internasional, mencatat, perbankan Indonesia memiliki profitabilitas tertinggi dibandingkan empat negara di ASEAN lainnya, yakni Malaysia, Filiphina, Singapura, Thailand, dan Vietnam.

Senior Director, Head of Financial Institutions-South and Southeast Asia Fitch Ratings Ambreesh Srivastava mengatakan di dalam artikel Jawa Pos tersebut, sepanjang 2012 Indonesia menunjukkan tingkat profitabilitas yang mengesankan. Hal tersebut terlihat dari rasio keuntungan terhadap asset (RoAA/return on average assets) secara nasional yang mencapai 2.5 persen. Torehan itu berada jauh diatas Malaysia yang hanya berada di kisaran 1.0-1.5 persen. Vietnam hanya mencatat rasio dikisaran 0.1-1.5 persen. Vietnam hanya mencatat rasio dikisaran 0.5-1.0 persen. Menurut Ambreesh, mayoritas perbankan di Indonesia mencatatkan rekam jejak RoA (return on assets) yang cukup tinggi selama tiga tahun terakhir. Saat ini BRI masih menjadi bank dengan tingkat RoA tertinggi dikisaran 3.5-4 persen. Berikutnya ada Danamon, BCA, dan Mandiri dengan rata-rata RoA dikisaran 2.5-3.0 persen. Dari sisi forecast, Ambreesh mengatakan bahwa pencapaian RoAA Indonesia tahun ini diproyeksi masih yang tertinggi. Tetapi pertumbuhannya moderat dibandingkan dua tahun terakhir. Misalnya, dalam enam tahun terakhir, RoAA Indonesia paling tinggi berada pada 2011, yakni dikisaran 2.5-3.0 persen. Tahun ini RoAA diperkirakan hanya berada di angka 2.0-3.0 persen. Tahun ini RoAA diperkirakan hanya berada di angka 2.0-2.5 persen.

Tabel 1. Tingkat Pengembalian Aset Rata-Rata (Return on Average Assets/RoAA) Perbankan ASEAN

\begin{tabular}{ccc}
\hline Tahun & 2012 & $2013^{*}$ \\
\hline Indonesia & 2.5 persen & $2.0-2.5$ persen \\
\hline Malaysia & $1.0-1.5$ persen & $1.0-1.5$ persen \\
\hline Filipina & $1.5-2.0$ persen & $1.5-2.0$ persen \\
\hline Singapura & $1.0-1.5$ persen & $0.5-1.0$ persen \\
\hline Thailand & 1.5 persen & $1.0-1.5$ persen \\
\hline Vietnam & $0.5-1.0$ persen & $0.5-1.0$ persen \\
\hline
\end{tabular}

Sumber Data : Jawa Pos, Kamis 7 Februari 2013

Lalu bagaimana dengan Bank syariah di Indonesia dalam kaitannya peningkatan profitabilitas bank? Secara operasional bank syariah berbeda dengan bank konvensional. Profitabilitas merupakan indikator yang paling penting untuk mengukur kinerja suatu bank. Menurut Lukman (2005) profitabilitas merupakan kemampuan bank untuk menghasilkan/memperoleh laba secara efektif dan efisien. Menurut Brigham dan Houston (2010:146) Untuk mengukur profitabilitas bank, biasanya menggunakan rasio profitabilitas karena rasio profitabilitas sudah mencakup rasio utang, rasio aktivitas maupun rasio likuiditas yang terdiri dari ROE (Return On Equity) yaitu rasio yang menggambarkan besarnya kembalian atas modal untuk menghasilkan keuntungan, dan ROA (Return On Asset) yaitu rasio yang menunjukkan kemampuan dari keseluruhan asset yang ada dan digunakan untuk menghasilkan keuntungan. Selain itu, dalam penentuan tingkat kesehatan suatu bank, Bank Indonesia lebih mementingkan penilaian 
ROA daripada ROE karena Bank Indonesia lebih mengutamakan nilai profitabilitas suatu bank yang diukur dengan asset yang dananya sebagian besar berasal dari dana simpanan masyarakat sehingga ROA lebih mewakili dalam mengukur tingkat profitabilitas perbankan. Semakin besar ROA suatu bank, semakin besar pula tingkat keuntungan yang dicapai bank tersebut dan semakin baik pula posisi bank tersebut dari segi penggunaan asset (Lukman, 2005). (Defri, 2012)

Oleh karena Return On Asset (ROA) penting dalam mengukur profitabilitas suatu bank, dimana menggambarkan kemampuan suatu bank dalam memperoleh laba secara keseluruhan. Maka faktor utama yang mempengaruhi profitabilitas bank menurut Machfoedz (1999) adalah manajemen. Yaitu seluruh manajemen suatu bank, salah satunya baik yang mencakup manajemen permodalan (CAR), manajemen umum, manajemen rentabilitas (BOPO), dan manajemen likuiditas (LDR) pada akhirnya akan mempengaruhi dan bermuara pada perolehan laba (profitabilitas) perusahaan perbankan. (Defri, 2012).

Berdasarkan uraian di atas, sebenarnya belum banyak yang meneliti pengaruh internal terhadap profitabilitas bank khususnya di industri Bank Umum Syariah di Indonesia. Oleh sebab itu, tujuan penelitian ini adalah untuk mengetahui dan menganalisis pengaruh tingkat rasio kesehatan bank yang dukur dengan CAR, FDR, dan BOPO terhadap peningkatan profitabilitas industri Bank Umum Syariah di Indonesia.

\section{KAJIAN TEORITIS}

\section{Pengaruh CAR Terhadap Profitabilitas (ROA)}

Capital Adequacy Rasio merupakan rasio kinerja bank untuk mengukur kecukupan modal yang dimiliki oleh bank untuk menunjang aktiva yang mengandung atau menghasilkan resiko. Modal merupakan salah satu faktor penting dalam rangka pengembangan usaha bisnis dan menampung resiko kerugian, semakin tinggi CAR maka semakin kuat kemampuan bank tersebut untuk menanggung resiko dari setiap kredit/aktiva produktif yang berisiko. (Ruslim, 2012).

Jika nilai CAR tinggi (sesuai ketentuan BI 8\%) berarti bank tersebut mampu membiayai operasional bank, keadaan yang menguntungkan bank tersebut akan memberikan kontribusi yang cukup besar bagi profitabilitas. Dalam menelaah CAR bank syariah, terlebih dahulu harus dipertimbangkan, bahwa aktiva bank syariah dapat dibagi atas: a) Aktiva yang didanai oleh modal sendiri dan/kewajiban atau hutang (wadiah atau qard dan sejenisnya). b) Aktiva yang didanai oleh rekening bagi hasil (Profit and loss Sharing Investment Account) yaitu mudharabah (General Investment Account/mudharabah mutlaqah, Restricted InvestmentAccount/mudharabah muqayyadah). CAR diukur dengan membagi modal dengan aktiva tertimbang menurut resiko (ATMR) berdasarkan PBI No. 10/15/PBI/2008 tanggal 24 September 2008 (Ruslim, 2012)

$$
C A R=\frac{\text { Modal Bank }}{\text { Total ATMR }} \times 100 \%
$$

\section{Pengaruh LDR/FDR Terhadap Return on Asset (ROA)}

Menurut Simorangkir (2004:147), Loan to Deposit Ratio dinyatakan sebagai : "Loan to Deposit Ratio merupakan perbandingan antara kredit yang diberikan dengan dana pihak ketiga, termasuk pinjaman yang diterima, tidak termasuk pinjaman 
subordinasi." Sedangkan menurut Kasmir (2003:272) Loan to Deposit Ratio adalah "Rasio yang digunakan untuk mengukur komposisi jumlah kredit yang diberikan dibandingkan dengan jumlah dana masyarakat dan modal sendiri yang digunakan." (Ruslim, 2012).

Rasio ini menggambarkan kemampuan bank membayar kembali penarikan yang dilakukan nasabah deposan dengan mengandalkan kredit yang diberikan sebagai sumber likuiditasnya. Semakin tinggi rasio ini semakin rendah kemampuan likuiditas bank. Loan to Deposit Ratio mempunyai peranan yang sangat penting sebagai indikator yang menunjukkan tingkat ekspansi kredit yang dilakukan bank sehingga LDR dapat juga digunakan untuk mengukur berjalan tidaknya suatu fungsi intermediasi bank. (Ruslim, 2012).

Menurut Kasmir (2002:186) batas aman LDR suatu bank secara umum adalah sekitar $81 \%-100 \%$. Sedangkan menurut ketentuan bank sentral, batas aman LDR suatu bank adalah $110 \%$. LDR dapat pula digunakan untuk menilai strategi manajemen suatu bank. Manajemen bank yang konservatif biasanya cenderung memiliki LDR yang relatif rendah, sebaliknya manajemen yang agresif memiliki LDR yang tinggi atau melebihi batas toleransi (Ruslim, 2012).

LDR merupakan ukuran likuiditas yang mengukur besarnya dana yang ditempatkan dalam bentuk kredit yang berasal dari dana yang dikumpulkan oleh bank (terutama dana masyarakat). Semakin tinggi LDR menunjukkan semakin riskan kondisi likuiditas bank, sebaliknya semakin rendah LDR menunjukkan kurangnya efektifitas bank dalam menyalurkan kredit. Semakin tinggi LDR maka semakin tinggi dana yang disalurkan ke dana pihak ketiga. Dengan penyaluran dana pihak ketiga yang besar maka bank akan pendapatan bank (ROA) akan semakin meningkat. Perhitungan untuk mencari LDR atau FDR adalah sebagai berikut (Defri, 2012)

$$
L D R \text { atau } F D R=\frac{\text { Jumlah kredit yang diberikan }}{\text { Jumlah kredit yang diberikan }} \times 100 \%
$$

\section{Pengaruh BOPO Terhadap Return on Asset (ROA)}

BOPO (Biaya Operasional/Pendapatan Operasional) dijadikan variabel independen yang mempengaruhi ROA didasarkan hubungannya dengan tingkat risiko bank yang bermuara pada profitabilitas bank (ROA). Menurut Veithzal, dkk (2007:722) BOPO adalah perbandingan antara biaya operasional dengan pendapatan operasional dalam mengukur tingkat efisiensi dan kemampuan bank dalam melakukan kegiatan operasinya. Semakin kecil rasio BOPO berarti semakin efisien biaya operasional yang dikeluarkan oleh bank yang bersangkutan, dan setiap peningkatan pendapatan operasi akan berakibat pada berkurangnya laba sebelum pajak yang pada akhirnya akan menurunkan laba atau profitabilitas (ROA) bank yang bersangkutan (Lukman, 2005). Berdasarkan ketentuan Bank Indonesia, besarnya BOPO yang normal berkisar antara 94\%-96\% (Lukman, 2005). Perhitungan untuk mencari BOPO adalah sebagai berikut (Veithzal, dkk, 2007) dalam (Defri, 2012)

$$
B O P O=\frac{\text { Biaya Operasional }}{\text { Pendapatan Operasional }} \times 100 \%
$$

\section{Profitabilitas}

Profitabilitas sebagai salah satu acuan dalam mengukur besarnya laba menjadi begitu penting untuk mengetahui apakah perusahaan telah menjalankan usahanya secara 
efisien. Efisiensi sebuah usaha baru dapat diketahui setelah membandingkan laba yang diperoleh dengan aktiva atau modal yang menghasilkan laba tersebut (Dhika, 2010).

Profitabilitas diukur dengan ROA yang mengukur kemampuan manajemen bank dalam memperoleh keuntungan (laba) secara keseluruhan (Lukman, 2005). ROA adalah rasio yang digunakan mengukur kemampuan bank menghasilkan keuntungan secara relative dibandingkan dengan total assetnya atau ukuran untuk menilai seberapa besar tingkat pengembalian dari asset perusahaan (Rudy, 2000:32). Dalam kerangka penilaian kesehatan bank, BI akan menentukan bank itu sehat apabila bank memiliki ROA diatas 1,215\% menurut SK DIR BI No. 30/12/KEP/DIR dan SEBI No. 30/3/UPPB masingmasing tanggal 30 April 1997 (Defri, 2012).

Jumlah modal bank memperngaruhi kemampuan bank memperoleh keuntungan. Untuk mengukur kemampuan bank memperoleh keuntungan dapat digunakan berbagai ukuran, salah satunya adalah return on asset (ROA).

$$
\text { Return On Asset }=\frac{\text { Laba Setelah Pajak }}{\text { Total Asset }}
$$

\section{Kajian Empirik}

Sabir, Ali, dan Hamid Habbe (2012) mengemukakan bahwa CAR tidak berpengaruh signifikan terhadap ROA, BOPO berpengaruh negatif dan signifikan terhadap ROA, NOM berpengaruh positif dan signifikan terhadap ROA, NPF tidak berpengaruh signifikan terhadap ROA, FDR berpengaruh positif dan signifikan terhadap ROA pada Bank Umum Syariah di Indonesia. CAR berpengaruh positif dan signifikan terhadap ROA, BOPO tidak berpengaruh terhadap ROA, NIM berpengaruh positif dan signifikan terhadap ROA, NPL berpengaruh negatif dan signifikan terhadap ROA, LDR berpengaruh negatif dan signifikan terhadap ROA pada Bank Konvensional di Indonesia.

Diuraikan pula oleh Dina Rizkiah Hutasuhut (2009) bahwa Financing to Deposit Ratio (FDR), Biaya Operasional terhadap Pendapatan Operasional (BOPO) dan Non Performing Financing (NPF) secara simultan berpengaruh signifikan terhadap profitabilitas (ROE) perbankan syariah pada tingkat kepercayaan 95\%. Pengujian secara parsial menunjukkan variabel FDR yang berpengaruh signifikan terhadap profitabilitas ROE perbankan syariah pada tingkat kepercayaan $95 \%$.

Selain itu, Dhika Rahma Dewi (2010) meneliti di Bank Syariah pula, didapatkan hasil bahwa Capital Adequacy Ratio (CAR) tidak berpengaruh signifikan terhadap ROA pada Bank Syariah di Indonesia, Financing to Deposit Ratio (FDR) tidak berpengaruh signifikan terhadap ROA pada Bank Syariah di Indonesia, Non Performing Financing (NPF) berpengaruh signifikan negatif terhadap ROA pada Bank Syariah di Indonesia, Rasio Efisiensi Operasional (REO) berpengaruh signifikan negatif terhadap ROA pada Bank Syariah di Indonesia.

Penelitian yang dilakukan oleh Defri pada Jurnal Manajemen, Volume 01, Nomor 01, September 2012 yang menggunakan variabel Capital Adequacy Ratio (CAR), Likuiditas dan Efisiensi Operasional guna mengetahui ada tidaknya pengaruh terhadap Profitabilitas Perusahaan Perbankan yang Terdaftar di BEI. Yakni, CAR berpengaruh positif dan tidak signifikan terhadap ROA pada perusahaan perbankan yang terdaftar di BEI, LDR berpengaruh positif dan tidak signifikan terhadap ROA pada perusahaan perbankan yang terdaftar di BEI, dan BOPO berpengaruh negatif dan signifikan terhadap ROA pada perusahaan perbankan yang terdaftar di BEI. Data diambil 
sebanyak 57 untuk dijadikan sampel dari 19 perusahaan perbankan pada periode pengamatan (2008-2010). Dan analisis nya menggunakan analisis regresi berganda.

Ida Rupaida (2012) dengan analisis faktor internal dan faktor eksternal terhadap profitabilitas, kasus pada PT. Bank NTB cabang Sumbawa Besar. Pengaruh internal yang digunakan untuk menguji profitabilitas secara parsial dan serentak bank yakni terdiri dari kredit, NPL, dan LDR. Data observasi menggunakan 63 data, yaitu data bulanan periode Januari 2006-Agustus 2011. analisis regresi linear berganda, dilengkapi dengan uji asumsi klasik dan uji signifikansi. NPL, LDR tidak memberikan pengaruh yang signifikan secara parsial terhadap pencapaian ROA PT. Bank NTB Cabang Sumbawa Besar. Variabel yang memberikan pengaruh signifikan hanya nilai kredit yang disalurkan oleh PT. Bank NTB Cabang Sumbawa Besar. Adapun pengujian secara serentak memberikan temuan bahwa terdapat pengaruh yang signifikan secara simultan dari nilai kredit, NPL, LDR, terhadap pencapaian ROA PT. Bank NTB Cabang Sumbawa Besar. Variabel yang berpengaruh dominan dan satu-satunya yang memberikan pengaruh yang signifikan terhadap pencapaian ROA PT. Bank NTB Cabang Sumbawa Besar hanya nilai kredit.

Vera Kristiana (2012) meneliti tentang pengaruh faktor internal bank terhadap profitabilitas pada Bank Go Public di Indonesia. DPK, NPL, CAR, Ekspansi Kredit secara simultan memiliki pengaruh yang signifikan terhadap profitabilitas pada bank yang go public di Indonesia. Secara parsial Dana Pihak Ketiga dan Capital Adequacy Ratio berpengaruh secara signifikan terhadap profitabilitas pada perusahaan perbankan yang go public di Indonesia. Non Performing Loan (NPL) dan Ekspansi Kredit tidak berpengaruh secara signifikan terhadap profitabilitas pada perusahaan perbankan yang go public di Indonesia. Dana Pihak Ketiga (DPK) merupakan variabel yang paling berpengaruh terhadap profitabilitas perusahaan.

Pandu Mahardian (2008) Hasil penelitian menunjukkan bahwa variabel CAR, NIM, dan LDR berpengaruh positif dan signifikan terhadap ROA serta BOPO berpengaruh negatif dan signifikan terhadap ROA. Sementara untuk variabel NPL memiliki pengaruh negatif terhadap ROA, akan tetapi tidak signifikan. Dari keempat variable yang signifikan, variable BOPO mempunyai pengaruh yang paling besar terhadap ROA yaitu dengan koefisien -3,404. Dengan demikian pihak bank (emiten) diharapkan lebih memperhatikan tingkat efisiensi operasinya untuk meningkatkan profitabilitas pada kinerja keuangannya. Kemudian penjelasan mengenai tidak signifikannya variable NPL terhadap ROA adalah selama periode penelitian, fungsi intermediasi bank tidak berjalan dengan baik.

Mawardi, Wisnu (2005). Hasil dari penelitianya menunjukkan bahwa keempat variable CAR, NPL, BOPO, serta NIM secara bersama sama mempengaruhi kinerja bank umum. Untuk variable CAR dan NIM mempunyai pengaruh positif terhadap ROA, sedangkan variabel BOPO dan NPL, mempunyai pengaruh negatif terhadap ROA. Dari keempat variabel, yang paling berpengaruh terhadap ROA adalah variabel NIM.

Ahmad Buyung (2009) dari hasil analisis menunjukkan bahwa data NPL, CAR, LDR, dan BOPO secara parsial signifikan terhadap ROA bank go publik pada level of signifikan kurang dari 5\%. Sedangkan pada bank non go public, hanya LDR yang berpengaruh signifikan. Hasil pengujian menghasilkan nilai Chow test F sebesar 3,372. Nilai F tabel diperoleh sebesar 1,96. Dengan demikian diperoleh nilai Chow test $(3,372)$ 
Email : megaaktiva@febi.umkendari.ac.id

Website : https://megaaktiva.umkendari.ac.id/index.php/Jurnal

$>\mathrm{F}$ tabel $(1,96)$. Hal ini berarti terdapat perbedaan pengaruh yang signifikan dari pengaruh 4 variabel bebas tersebut terhadap ROA pada bank go publik dan bank non go publik.

\section{METODE PENELITIAN}

Penelitian ini merupakan penelitian kausatif. Data yang dipakai dalam penelitian ini adalah data sekunder antara lain capital adequacy ratio (CAR), likuiditas (FDR), efisiensi operasional (BOPO) dan profitabilitas (ROA) pada industri perbankan umum syariah yang terdaftar di Bank Indonesia. Data tersebut merupakan data time series cross section dari tahun 2010-2012 dan 2013 (hanya pada bulan Januari hingga Maret 2013) yang diperoleh melalui situs resmi statistik perbankan, Bank Indonesia (www.bi.go.id). Untuk menganalisisnya, peneliti menggunakan model regresi linear berganda dengan SPSS 16.

\section{HASIL DAN PEMBAHASAN}

Hasil analisis dari penelitian ini, berdasarkan pada model regresi linear berganda yaitu guna menguji pengaruh antara $\mathrm{CAR}\left(\mathrm{X}_{1}\right)$, FDR $\left(\mathrm{X}_{2}\right)$, BOPO $\left(\mathrm{X}_{3}\right)$ terhadap profitabilitas industri Bank Syariah di Indonesia yang diukur dengan ROA, dapat terlihat pada tabel.

Tabel 2. Hasil Estimasi Regresi Linear Berganda Pengaruh CAR, FDR, dan BOPO Terhadap Profitabilitas Industri Bank Syariah di Indonesia (pada $\alpha=0,05$ )

\begin{tabular}{|c|c|c|c|c|c|c|}
\hline Variabel & Coefficient & $\mathrm{t}(\mathrm{sig})$ & $\mathrm{R}$ & $\mathrm{R}^{2}$ & $\mathrm{~F}$ & Sig \\
\hline ROA (Constant) & 8.862 & $12.784(0.000)$ & \multirow{4}{*}{0.906} & \multirow{4}{*}{0.821} & \multirow{4}{*}{50.330} & \multirow{4}{*}{0.000} \\
\hline $\operatorname{CAR}\left(\mathrm{X}_{1}\right)$ & 0.004 & $0.339(0.737)$ & & & & \\
\hline $\mathrm{FDR}\left(\mathrm{X}_{2}\right)$ & -0.003 & $-1.918(0.064)$ & & & & \\
\hline $\mathrm{BOPO}\left(\mathrm{X}_{3}\right)$ & -0.086 & $-12.038(0.000)$ & & & & \\
\hline
\end{tabular}

Dari data yang berhasil diolah diatas, didapatkan hasil bahwa hubungan antara CAR, FDR, dan BOPO terhadap ROA yang merupakan indikator kesehatan Bank untuk mengukur profitabilitasnya yakni sebesar 0.906. Artinya memiliki hubungan yang tinggi.

Berdasarkan hasil estimasi pada olahan data tersebut, terlihat bahwa variasi perubahan antara variabel independent yaitu CAR $\left(\mathrm{X}_{1}\right)$, FDR $\left(\mathrm{X}_{2}\right)$, dan BOPO $\left(\mathrm{X}_{3}\right)$ terhadap variabel dependent yaitu ROA (Y) adalah sebesar 0.821 atau sebesar $82 \%$, sedangkan sisanya yaitu sebesar $16 \%$ dipengaruh oleh variabel lain yang belum masuk dalam model estimasi penelitian ini.

CAR di peroleh dengan hasil uji statistik yang dilakukan memiliki pengaruh positif terhadap profitabilitas ( ROA ). Hasil uji t yang menunjukkan variabel CAR memiliki nilai signifikansi sebesar 0,737 yang lebih besar dari 0,05 artinya variabel CAR secara parsial tidak berpengaruh signifikan terhadap profitabilitas. Sejalan penelitian terhadap bank syariah yang dilakukan oleh Muh. Sabir. M, dkk., bahwa variabel CAR tidak berpengaruh terhadap ROA pada Bank Umum Syariah. Tidak berpengaruhnya CAR 
terhadap ROA disebabkan karena bank-bank yang beroperasi tidak mengoptimalkan modal yang ada, Hal ini terjadi karena peraturan Bank Indonesia yang mensyaratkan CAR minimal sebesar $8 \%$ mengakibatkan bank-bank selalu berusaha menjaga agar CAR yang dimilikinya sesuai dengan ketentuan. Penelitian ini didukung oleh Dewi (2010), Wisnu Mawardi (2005), dan tidak didukung oleh Buyung (2009).

Sedang FDR di peroleh dengan hasil uji statistik yang dilakukan memiliki pengaruh positif terhadap profitabilitas ( ROA ). Hasil uji t yang menunjukkan variabel FDR memiliki nilai signifikansi sebesar 0.064 yang lebih besar dari 0,05 artinya variabel FDR secara parsial berpengaruh negatif dan tidak signifikan terhadap profitabilitas. Penyaluran pembiayaan kepada calon nasabah dilakukan dengan memperhatikan prinsip 5C yang terdiri atas yaitu Character (karakter), Capacity (kemampuan pengembalian), Collateral (jaminan), Capital (modal), dan Condition (situasi dan kondisi). Penelitian ini didukung Dewi (2010) dan tidak didukung oleh Hutasuhut (2009).

CAR dan FDR sama-sama tidak berpengaruh signifikan terhadap ROA. Namun CAR secara parsial berpengaruh positif, sedangkan FDR berpengaruh negative. Berbeda lagi dengan BOPO yang secara parsial berpengaruh negative dan signifikan terhadap ROA karena nilainya 0.000 yang berarti lebih kecil dari 0.05 . Hasil penelitian seirama dengan penelitian Muh. Sabir. M, dkk., Hal ini ditunjukkan bahwa BOPO berpengaruh negatif dan signifikan terhadap ROA pada Bank Umum Syariah. Nilai negative yang ditunjukkan BOPO menunjukkan bahwa semakin kecil BOPO menunjukkan semakin efisien bank dalam menjalankan aktifitas usahanya, BOPO yang kecil menunjukkan bahwa biaya operasional bank lebih kecil dari pendapatan operasionalnya sehingga hal tersebut menunjukkan bahwa manajemen bank sangat efisien dalam menjalankan aktivitas operasionalnya. Penelitian ini didukung oleh Setiawan (2009), Mawardi (2005). Adapun pengujian secara serentak memberikan temuan bahwa terdapat pengaruh yang signifikan secara simultan dari nilai CAR, FDR dan BOPO terhadap pencapaian ROA di Industri Bank Syariah di Indonesia.

Menurut penelitian yang pernah dilakukan oleh Muh. Sabir. M, Muhammad Ali, Abd. Hamid Habbe (2012), Ditemukan perbedaan ROA Bank Umum Syariah dan Bank Konvensional. terdapat perbedaan yang signifikan antara return on asset Bank Umum Syariah dengan return on asset Bank Konvensional. secara operasional bank syariah berbeda dengan bank konvensional. Oleh karena itu, besar kemungkinan kinerja keuangan yang dihasilkan dari sistem operasional yang berbeda menghasilkan kinerja keuangan yang berbeda pula.

\section{KESIMPULAN}

Dari hasil pengamatan dan analisis data yang telah dilakukan, kesimpulan pada penelitian ini adalah CAR, FDR, dan BOPO terhadap ROA yang merupakan indikator kesehatan Bank untuk mengukur profitabilitasnya memiliki hubungan yang tinggi. CAR secara parsial tidak berpengaruh signifikan terhadap profitabilitas. Tidak berpengaruhnya CAR terhadap ROA disebabkan karena bank-bank yang beroperasi tidak mengoptimalkan modal yang ada, Hal ini terjadi karena peraturan Bank Indonesia yang mensyaratkan CAR minimal sebesar $8 \%$ mengakibatkan bank-bank selalu berusaha menjaga agar CAR yang dimilikinya sesuai dengan ketentuan. Sedangkan variabel FDR secara parsial berpengaruh negatif dan tidak signifikan terhadap 
profitabilitas. Berbeda lagi dengan BOPO yang secara parsial berpengaruh negatif dan signifikan terhadap ROA. ROA Bank Umum Syariah dan Bank Konvensional. terdapat perbedaan yang signifikan antara return on asset Bank Umum Syariah dengan return on asset Bank Konvensional. Secara operasional bank syariah berbeda dengan bank konvensional. Disarankan bagi manajemen bank untuk lebih menjaga rasio internal bank untuk meningkatkan profitabilitas, khususnya industri Bank Umum Syariah di Indonesia. Penelitian ini dapat lebih dikembangkan, karena penelitian serupa untuk mengetahui faktor-faktor yang dapat mempengaruhi profitabilitas industri Bank Umum Syariah di Indonesia belum banyak dan tidak sebanding dengan penelitian pada Bank Konvensional.

\section{DAFTAR PUSTAKA}

Buyung, Ahmad. 2009. Analisis pengaruh NPL,CAR, LDR, dan BOPO Terhadap profitabilitas bank (Perbandingan Bank Umum Go Publik dan Bank Umum Non Go Publik di Indonesia Periode Tahun 2005-2007), Tesis, Universitas Deponegoro, Semarang.

Defri. 2012. "Pengaruh Capital Adequacy Ratio (CAR), Likuiditas dan Efisiensi Operasional Terhadap Profitabilitas Perusahaan Perbankan yang Terdaftar di BEI”. Jurnal Manajemen, Volume 01, Nomor 01, September 2012.

Haron, Sudin. 2004. "Determinant of Islamic Bank Profitability". The paper is published in the Global Journal of Finance and Economics. USA, Vol 1, No 1, March 2004.

Hutasuhut, Dina Rizkiah, 2009. Pengaruh FDR, BOPO dan NPF terhadap profitabilitas perbankan syariah di Indonesia, skripsi, Universitas Sumatra Utara, Medan.

Mahardian, Pandu, 2008. Analisis Pengaruh Rasio CAR, BOPO, NPL, NIM dan LDR Terhadap Kinerja Keuangan Perbankan (Studi Kasus Perusahaan Perbankan Yang Tercatat Di Bej Periode Juni 2002 - Juni 2007).

Mawardi, Wisnu, 2005. “Analisis Faktor-faktorYang Mempengaruhi Kinerja Keuangan Bank Umum di Indonesia (Studi Kasus Pada Bank Umum Dengan Total Assets Kurang Dari 1 Triliun)”. Jurnal Bisnis dan Strategi. Vol.14. No.1. Juli 2005

Naceur, Ben Samy, 2003. The Determinants Of The Tunisian Banking Industry Profitability: Panel Evidence.

Rahma Dewi, Dhika, 2010. Faktor-Faktor Yang Mempengaruhi Profitabilitas Bank Syariah Di Indonesia, Skripsi, Universitas Deponegoro, Semarang.

Rupaida, Ida, 2012. Analisis Faktor Internal dan Faktor Eksternal Terhadap Profitabilitas; (Kasus pada PT. Bank NTB Cabang Sumbawa Besar).

Ruslim, 2012. "Analisis Pengaruh Capital Adequancy Ratio (CAR), Non Performing Loan (NPL), dan Loan to Deposit Ratio (LDR) Terhadap Return On Asset (ROA) Pada Bank Umum Syariah Yang Terdaftar Di Bank Indonesia”.

Sabir. M, Muh, dkk. 2012. Pengaruh Rasio Kesehatan Bank Terhadap Kinerja Keuangan Bank Umum Syariah Dan Bank Konvensional Di Indonesia”. Jurnal Analisis, Juni, Vol.1 No.1 : $79-86$. 
Siamat, Dahlan, 2005. Manajemen Lembaga Keuangan: Kebijakan Moneter dan Perbankan. Edisi Kelima. Jakarta: Lembaga Penerbit Fakultas Ekonomi Universitas Indonesia.

www.bi.go.id 